\title{
PENINGKATAN PENGUASAAN KONSEP MATEMATIKA MELALUI MODEL PEMBELAJARAN KOOPERATIF TIPE STAD
}

\author{
Aswin Saputra ${ }^{1}$, Ade Lukman Nulhakim ${ }^{2}$ \\ Program Studi Informatika, Universitas Indraprasta PGRI ${ }^{1,2}$ \\ Email: saputraaswin133@gmail.com ${ }^{1}$
}

\begin{abstract}
Abstrak
Tujuan penelitian ini adalah untuk mengetahu peningkatan penguasaan siswa kelas VIII-2 melalui model pembelajaran kooperatif tipe STAD di MTs Negeri 40 Jakarta Barat. Metode yang digunakan dalam penelitian ini adalah pendekatan kualitatif dengan teknik penelitian tindakan kelas, yaitu suatu tindakan yang dilakukan oleh guru untuk memperbaiki pengajaran dengan cara melakukan perubahan dan mempelajari akibat dari perubahan itu. Teknik yang digunakan dalam pengumpulan data adalah: tes akhir siklus dan observasi. Hasil penelitian menunjukkan bahwa proses pembelajaran Matematika dengan penerapan model kooperatif tipe STAD mampu memperbaiki hasil belajar siswa menjadi lebih baik. Hasil yang diperoleh daya serap pada siklus I adalah $51.163 \%$, kemudian diperbaiki pada siklus II dengan hasil daya serap kelas adalah $90.69 \%$. Hal ini menunjukkan kemajuan dimana siswa telah mendapatkan hasil belajar yang baik dari siklus I.
\end{abstract}

Kata kunci: Penguasaan Konsep, Model Pembelajaran Kooperatif

\begin{abstract}
The purpose of this research is to know the increase in concept mastery of students class VIII-2 through STAD type cooperative learning model in MTs Negeri 40, West Jakarta. The method used in this research is a qualitative approach with a classroom action research technique, which is an action performed by the teacher to improve teaching by making changes and studying the consequences of the changes. Techniques used in data collection are: end of cycle test and observation. The results show that the process of learning mathematics with the application of STAD type cooperative model can make student's learning outcomes better. The result obtained is the absorption class in cycle I is $51.163 \%$, then repaired in cycle II with the absorption class of $90.69 \%$. This shows progress that the students have obtained good learning outcomes from cycle I.
\end{abstract}

Keywords: Concept Mastery, Cooperative Learning Model

\section{PENDAHULUAN}

Penyelenggaraan pendidikan yang berkualitas adalah salah satu cara dalam mewujudkan cita-cita kemerdekaan Indonesia sebagaimana yang diamantkan dalam pembukaan Undang-Undang Dasar Negara Republik Indonesia tahun 1945, yaitu memajukan kesejahteraan umum dan mencerdaskan kehidupan bangsa. Pendidikan merupakan salah satu faktor yang sangat penting dalam hal mewujudkan bakat-bakat yang dibawa manusia sejak lahir, sehingga manusia memiliki keterampilan yang dapat digunakan untuk menghidupi dirinya. Pendidikan inilah yang diharapkan akan menghasilkan manusia-manusia yang berkualitas.
Pendidikan yang bermutu merupakan salah satu prioritas utama dalam pembangunan nasional. Pendidikan yang menghasilkan perubahan sikap dan tingkah laku manusia baik yang berupa pengetahuan maupun keterampilan akan membawa kemajuan suatu bangsa. Pentingnya pendidikan inilah yang menuntut adanya proses pendidikan yang optimal sehingga menghasilkan pendidikan yang bermutu.

Berikut ini data pengujian tingkat kemampuan kognisi siswa yang terstandarisasi dilakukan oleh Programe for International Student Assessment (PISA). 
Tabel 1. Posisi Indonesia dalam hasil tes kemampuan kognisi dibanding dengan beberapa negara terseleksi tahun 2012

\begin{tabular}{|c|c|c|c|c|c|c|c|c|}
\hline \multirow[b]{2}{*}{ Negara } & \multicolumn{4}{|c|}{ Matematika } & \multicolumn{2}{|c|}{ Membaca } & \\
\hline & Rerata & $\begin{array}{l}\text { Skor } \\
\text { rendah }\end{array}$ & $\begin{array}{l}\text { Skor } \\
\text { tinggi }\end{array}$ & $\begin{array}{l}\% \\
\text { kenaikan/tahun }\end{array}$ & Rerata & $\begin{array}{l}\% \text { kenaikan/ } \\
\text { tahun }\end{array}$ & Rerata & \\
\hline $\begin{array}{l}\text { Shanghai } \\
(\mathrm{Xt})\end{array}$ & 613 & 3,8 & 55,4 & 4,2 & 496 & 0,3 & 501 & 501 \\
\hline Peru $(\mathrm{Xr})$ & 368 & 0,6 & 74,6 & 1,0 & 384 & 5,2 & 373 & 373 \\
\hline $\begin{array}{l}\text { Rerata } \\
\text { OECD }\end{array}$ & 496 & 23,1 & 12,6 & $-0,3$ & 496 & 0,3 & 501 & 501 \\
\hline Indonesia & 375 & 75,7 & 0,3 & 0,7 & 396 & 2,3 & 382 & $\overline{-}$ \\
\hline Singapura & 573 & 8,3 & 55,4 & 3,8 & 542 & 5,4 & 580 & 1,8 \\
\hline Korea & 554 & 9,1 & 30,9 & 1,1 & 536 & 0,9 & 538 & 2,6 \\
\hline Vietnam & 511 & 14,2 & 13,3 & NA & 508 & NA & 528 & NA \\
\hline Thailand & 427 & 49,7 & 2,6 & 1,0 & 441 & 1,1 & 444 & 3,9 \\
\hline Malaysia & 421 & 51,8 & 1,3 & 8,1 & 398 & $-7,8$ & 420 & $\begin{array}{l}- \\
1,4\end{array}$ \\
\hline Brazilia & 391 & 67,1 & 0,8 & 4,1 & 410 & 1,2 & 405 & 2,3 \\
\hline
\end{tabular}

Apabila dibandingkan dengan empat kelompok Negara yang lain. Vietnam, Thailand, Malaysia, dan Brazilia, capaian rerata skornya di atasnya. Di Indonesia relatif belum ada, terbukti dengan naiknya presentase perolehan skor per tahun Indonesia sangat rendah, yaitu hanya $0,7 \%$ dan 2,3\% masing-masing untuk pelajaran bidang matematika dan membaca, sementara untuk IPA bahkan turun 1,9\%. Bandingkan dengan Thailand, Malaysia, dan Brazilia yang memperoleh kenaikan presentase skor bidang matematika masing-masing $1: 8: 1$ dan $4,1 \%$.

Rendahnya nilai hasil belajar siswa juga terjadi pada siswa kelas VIII-2 MTsN 40 Jakarta terutama pada pembelajaran matematika. Sebagai contohnya, saat guru memberikan ulangan harian materi SPLDV kebanyakan siswa salah mengoperasikan perhitungan aljabar.

Akibatnya lebih dari $70 \%$ siswa belum tuntas belajar dengan rerata ulangan harian kurang dari batas kriteria ketuntasan minimal (KKM) yaitu 70. Hal ini dapat diketahui dari hasil rerata nilai ulangan harian sebagai berikut:
Tabel 2. Rerata hasil ulangan harian materi SPLDV

\begin{tabular}{ccc}
\hline Tahun Pelajaran & Jumlah siswa & Rerata nilai \\
\hline 2013 / 2014 & 37 & 62 \\
2014 / 2015 & 39 & 66 \\
\hline \multicolumn{2}{c}{ Sumber: Daftar Nilai Guru Matematika MTs Negeri 40 } \\
Jakarta
\end{tabular}

Berdasarkan data di atas, menunjukkan bahwa kemampuan penguasaan konsep matematika masih rendah. Hal ini teridentifikasi dari kegiatan menyelesaikan soal-soal yang menuntut kemampuan siswa untuk berpikir, masih banyak siswa yang belum mampu memahami apa maksud yang terdapat dalam soal tersebut. Hal ini dapat dikatagerorikan bahwa kemampuan penguasaan konsep matematika siswa rendah.

Faktor yang menyebabkan rendahnya hasil belajar siswa dikarenakan guru dalam menerangkan materi matematika kurang menarik perhatian siswa sebab guru cenderung menggunakan metode ceramah atau pembelajaran secara konvensional sehingga mengakibatkan sebagian siswa bersikap pasif selama proses belajar mengajar berlangsung. Hal itu menjadikan kondisi belajar mengajar tidak kondusif yang dapat menimbulkan tidak adanya 
minat belajar siswa terhadap pelajaran matematika dan berakibat pada hasil belajar yang diperoleh siswa cenderung rendah.

Keadaan ini merupakan hal yang harus diperhatikan mengingat pentingnya mata pelajaran Matematika dalam menyiapkan siswa untuk mampu memecahkan permasalahan, salah satunya dengan memiliki kemamapuan penguasaan konsep matematika. Penguasaan materi-materi Matematika merupakan hal yang mutlak sehingga dapat dipahami dalam diri siswa untuk kemudian akhirnya mampu memecahkan permasalahan.

Berdasakan paparan di atas, judul yang diambil adalah "Upaya Perbaikan Penguasaan Konsep Matematika Siswa Kelas VIII di MTs Negeri 40 melalui Model Pembelajaran Kooperatif Tipe STAD”. Penelitian ini dilakukan karena perlu adanya peningkatan kemampuan penguasaan konsep siswa dalam pembelajaran matematika, maka salah satu tujuan pembelajaran matematika yaitu memahami konsep matematika, menjelaskan keterkaitan antarkonsep, dan menerapkan konsep atau algoritma secara luwes, akurat, efisien, dan mampu memecahkan permasalahan yang berkaitan dengan SPLDV.

\section{METODE}

Metode yang digunakan dalam penelitian ini adalah metode penelitian tindakan kelas (Classrom Action Research). Penelitian tindakan kelas merupakan penelitian tindakan yang dilakukan yang bertujuan untuk memperbaiki mutu praktik pembelajaran di kelas [1] Melalui refleksi diri dengan tujuan untuk memperbaiki kinerjanya sebagai hasil belajar siswa meningkat [2]

Bentuk tindakan dirancang sesuai dengan karakteristik Penelitian Tindakan Kelas (PTK) dan dibatasi sampai pada dua siklus, dimana setiap siklus terdiri dari 4 tahap utama yaitu: tahap perencanaan (planing), tahap pelaksanaan tindakan (action), tahap observasi (observation) dan tahap analisis dan refleksi (reflection). Dalam setiap siklus dirancang dengan menerapkan model pembelajaran kooperatif tipe STAD untuk mencapai tujuan pembelajaran Matematika. Keberhasilan penelitian dilihat dari peningkatan Penguasaan Konsep Matematika dari setiap siklusnya.

Metode pengumpulan data yang digunakan dalam penelitian tindakan kelas ini yaitu menggunakan teknik observasi terhadap siswa di kelas. Dalam penelitian PTK ini teknik pengumpulan datanya adalah: (1) data awal, untuk mengetahui tingkat kemampuan siswa dalam memahami pelajaran, (2) data hasil belajar siswa dari nilai Lembar Kerja Siswa (LKS) dan hasil tes dari setiap akhir siklus, (3) Observasi terhadap proses pembelajaran dan respon siswa, dan (4) data tentang refleksi perubahan perubahan yang terjadi di kelas, yang diperoleh melalui catatan lapangan dan wawancara [3]

Ada dua kategori ketuntasan belajar yaitu secara perorangan dan sacara klasikal. Ketuntasan belajar siswa berdasarkan pada petunjuk teknis pelaksanaan belajar mengajar Kurikulum Tingkat Satuan Pendidikan (KTSP) MTs Negeri 40 pada mata pelajaran Matematika, masingmasing siswa dinyatakan tuntas belajar jika mencapai kriteria ketuntasan minimal (KKM) dengan nilai 75 .

Penelitian ini menggunakan teknik triangulasi dengan jalan memanfaatkan peneliti untuk keperluan pengecekan kembali derajat kepercayaan data. Pemanfaatan dalam hal ini adalah guru matematika kelas VIII-2 dan peneliti dapat membantu mengurangi kesalahan dalam pengumpulan data. Setelah data dan informasi yang diperlukan terkumpul 
seluruhya, langkah selanjutnya adalah analisis data. Sesuai dengan jenis datanya, maka untuk analisisnya akan digunakan teknik analisis deskriptif kualitatif.

Pada penelitian ini menggunakan teknik analisis deskriptif kualitatif, yaitu suatu metode penelitian yang bersifat menggambarkan kenyataan atau fakta sesuai dengan data yang diperoleh dengan tujuan untuk mengetahui prestasi belajar yang dicapai siswa juga untuk memperoleh respon siswa terhadap kegiatan pembelajaran serta aktivitas siswa selama proses pembelajaran. Untuk menganalisis tingkat keberhasilan atau persentase keberhasilan siswa setelah proses belajar mengajar setiap putarannya dilakukan dengan cara memberikan evaluasi berupa soal tes tertulis pada setiap akhir putaran.

Instrumen yang akan digunakan untuk pengumpulan dan penelitian ini adalah: (1) Lembar observasi terhadap proses pembelajaran dengan menggunakan model pembelajaran kooperatif tipe STAD, (2) Lembar observasi respon siswa, (3) Lembar kerja siswa berupa soal-soal yang berhubungan dengan materi yang diberikan kepada siswa, (4) Lembar penilaian hasil belajar siswa, dan (5). Lembar wawancara yang digunakan untuk mempertegas dan melengkapi data yang diperoleh dari observasi dan tes.

Kriteria keberhasilan dari pemberian tindakan ini adalah apabila pencapaian rata-rata kelas pada setiap siklus mengalami peningkatan signifikan dari prasiklus atau data awal sampai pada siklus ke II, siswa yang memenuhi KKM lebih dari $80 \%$ pada siklus ke II.

\section{HASIL DAN PEMBAHASAN}

Seperti telah dijelaskan sebelumnya, penelitian tindakan kelas ini dilakukan dalam 2 siklus. Pelaksanaan prosedur penelitian yang akan dilakukan adalah sebagai berikut:

1. Tahapan Pelaksanaan Siklus I

a) Tahap perencanaan tindakan Dalam tahap perencanaan tindakan pada siklus ini, kegiatan yang dilakukan adalah:

(1) Menyusun silabus yang berkaitan dengan materi SPLDV

(2) Merancang skenario pembelajaran yang dapat digunakan dalam model pembelajaran kooperatif tipe STAD

(3) Merancang alat pengumpul data berupa tes dan digunakan untuk mengetahui penguasaan konsep siswa yang berkaitan dengan materi SPLDV.

b) Tahap pelaksanaan tindakan

(1) Siswa diberikan penjelasan umum tentang tujuan penelitian tindakan kelas sesuai dengan rancangan yang telah direncanakan, baik mengenai pengumpulan data maupun kegiatan-kegiatan yang lain. Kegiatan dalam penelitian tindakan kelas ini adalah memberikan penjelasan secara umum tentang pokok bahasan yang diajarkan dengan menggunakan model pembelajaran kooperatif tipe STAD agar menstimulasi rasa ingin tahu siswa, mendorong siswa yang belum aktif untuk aktif dalam mengikuti pembelajaran, mengamati dan mencatat siswa yang berpartisipasi aktif dalam pembelajaran, mengumpulkan hasil pengujian yang diperoleh siswa dalam mengerjakan tugas , dan menganalisis haisl tes yang diberikan setelah siswa diajar dengan model 
pembelajaran kooperatif tipe STAD.

(2) Peneliti mengajar sesuai dengan skenario pembelajaran klasikal yang telah dirancang dan mencatat kegiatan-kegiatan yang dilakukan oleh masingmasing siswa.

(3) Memberikan evaluasi pada siswa untuk mengetahui pemahaman siswa berkaitan dengan materi SPLDV.

c) Tahap observasi tindakan

Mengamati dan mencatat semua kejadian yang terjadi pada saat siswa mengikuti pembelajaran dan menanyakan pada siswa yang kurang aktif dalam pembelajaran tentang kesulitan-kesulitan yang dihadapinya.

d) Tahap refleksi

Menganalisis hasil pekerjaan siswa dan hasil observasi yang dilakukan pada siswa guna menentukan langkah berikutnya. Membuat pengelompokkan siswa berdasarkan pada hasil yang didapatkan siswa pada evaluasi yang dilakukan.

\section{Tabel 3. Nilai Tes Siklus I}

\begin{tabular}{ccc}
\hline Interval Nilai & Presentasi & Frekuensi \\
\hline $50-59$ & $32,55 \%$ & 14 \\
$60-69$ & $11,628 \%$ & 5 \\
$70-79$ & $51,163 \%$ & 22 \\
$80-89$ & 4,651 & 2 \\
$90-99$ & - & 0 \\
Jumlah & $100 \%$ & 43 \\
\hline
\end{tabular}

Berdasarkan pengamatan yang telah dilakukan selama kegiatan siklus I, siswa kurang memahami soal mengenai Materi SPLDV. Siswa kesulitan untuk menentukan menyelesaikan setiap tipe soal yang diberikan. Hal ini dikarenakan kurang nalarnya siswa. Diskusi kelompok juga belum berjalan efektif dan masih banyak siswa yang kurang aktif saat berdiskusi dengan teman dalam kelompoknya. Maka guru sepakat untuk mengulang materi mengenai SPLDV, agar ditindak lanjuti ke siklus II

2. Tahapan Pelaksanaan Siklus II

a) Tahap perencanaan tindakan

(1) Mempersiapkan fasilitas dan sarana yaitu dengna membuat kelompok siswa dengan penyebaran siswa yang menguasai materi awal yaitu materi yang telah disampaikan pada siklus I.

(2) Membuat pengurus pada masing-masing kelompok yang fasilitator, pencatat, juru bicara, dan pengatur waktu.

(3) Membuat bahan ajar yang akan disampaikan pada masingmasing kelompok untuk didiskusikan

b) Tahap pelaksanaan tindakan

(1) Memberikan penjelasan tentang pokok bahasan SPLDV yang akan dipelajari serta menjelaskan kegiatan yang akan dilaksanakan berkaitan dengan pengajaran dalam teknik menstimulasi siswa untuk belajar bersama dalam kelompok

(2) Siswa yang telah menguasai materi awal disiklus I diminta memimpin pembahasan bahan ajar. Bahan ajar yang diberikan berisi tugas memecahkan masalah tindak lanjut dari siklus I.

(3) Memberi kesempatan kepada masing-masing kelompok untuk menyajikan hasil diskusi.

(4) Pembahasan materi ajar yang siswa dalam satu kelas mengalami kesulitan atau pun salah dalam apersepsinya.

(5) Mengevaluasi siswa untuk mengetahui kemampuan siswa dalam menguasai pengerjaan soal SPLDV. 
c) Tahap observasi tindakan

(1) Mencatat hasil-hasil yang diperoleh siswa serta mencatat kesalahan-kesalahan yang dilakukan siswa dalam mengerjakan masalah yang berkaitan dengan bahan ajar yang diberikan.

(2) Mencatat kesalahan-kesalahan yang dilakukan siswa dalam menyelesaikan masalah pada bahan ajar yang diberikan.

d) Tahap refleksi

Membuat inventarisasi kesulitan yang dilakukan siswa dalam menyelesaiakan masalah pada bahan ajar yang diberikan serta mendata siswa yang telah mampu menyelsaikan soal evaluasi dan mampu mendapatkan nilai di atas standar KKM.

Tabel 4. Nilai Tes Siklus II

\begin{tabular}{ccc}
\hline Interval Nilai & Presentasi & Frekuensi \\
\hline $50-59$ & - & - \\
$60-69$ & $2,326 \%$ & 1 \\
$70-79$ & $41,86 \%$ & 18 \\
$80-89$ & $46,512 \%$ & 20 \\
$90-99$ & $9,302 \%$ & 4 \\
Jumlah & $100 \%$ & 43 \\
\hline
\end{tabular}

Berdasarkan pada tabel di atas, bahwa tes formatif yang dilakukan setelah pembelajaran pada siklus II, nilai tertinggi dari hasil evaluasi siklus II adalah 98 dan terendah 66. Berdasarkan pengamatan yang telah dilakukan selama siklus II, diskusi kelompok berjalan aktif, suasana di kelas juga tertib dan tenang karena hampir seluruh siswa aktif berdiskusi dalam kelompoknya. Motivasi belajar siswa juga meningkat dengan penerapan model pembelajaran kooperatif tipe STAD ini.

Pada perencanaan guru menyusun Rencana Pelaksanaan Pembelajaran. Kemudian menentukan pokok bahasan tentang SPLDV. Dalam pelaksanaan tindakan, pembelajaran sesuai skenario yang telah dibuat. Dalam kegiatan observasi mengacu pada lembar observasi. Pada tahap yang terakhir yaitu refleksi melakukan evaluasi dan membahas hasil evaluasi tersebut dan mencermatinya.

Sesuai langkah-langkah model pembelajaran kooperatif tipe STAD yaitu: guru menyampaikan materi yang akan didiskusikan, siswa dibagi menjadi beberapa kelompok, masing-masing kelompok diberi materi untuk didiskusikan, guru membimbing jalannya diskusi, siswa mempresentasikan hasil diskusi, dan pemberian penghargaan pembelajaran matematika. Untuk mengetahui nilai siswa pada siklus I dapat dilihat pada tabel $1 \mathrm{di}$ atas

Berdasarkan tabel 2 di atas, dapat diketahui terdapat perbaikan atau peningkatan yang baik pada penguasaan konsep matematika siswa karena dari 43 siswa hanya terdapat 1 siswa yang nilai antara 60-69 dan sisanya memperoleh nilai di atas KKM.

Model pembelajaran kooperatif tipe STAD yang dilaksanakan guru telah mampu menumbuhkan dan meningkatkan motivasi belajar siswa sehingga penguasaan konsep matematika siswa kelas VIII-2 meningkat pula. Hal ini didukung oleh hasil penelitian Hendrik yang menyatakan bahwa, metode pembelajaran (metode pembelajaran kooperatif dan metode pembelajaran klasikal) membawa suatu akibat terhadap hasil belajar fisika apapun juga tingkat gaya kognitif siswa [4] , kemudian hasil penelitian Alfiliansi, dkk menyatakan bahwa model pembelajaran kooperatif tipe STAD berbantuan blok aljabar dapat meningkatkan hasil belajar siswa pada penjumlahan dan pengurangan [5], serta hasil penelitian dari Ni Made Sunilawati, dkk mengungkapkan bahwa bahwa untuk siswa yang memiliki kemampuan numerik tinggi yang mengikuti model pembelajaran kooperatif tipe STAD lebih unggul 
dibandingkan dengan siswa yang memiliki kemampuan numerik tinggi yang mengikuti model pembelajaran konvensional [6]

Tanggapan siswa terhadap model pembelajaran kooperatif tipe STAD cukup beragam, tetapi hampir semuanya menyatakan bahwa mereka menyukai model belajar mengajar ini, hal ini dilakukan oleh melalui pertanyaan guru saat bertanya kepada para siswa di kelas. Selain itu dengan penerapan model ini, secara garis besar siswa merasakaan, yaitu:

1. Siswa dapat semakin berinteraksi dengan guru dalam aktif bertanya, menyangga suatu pendapat ataupun mengoreksi kekeliruan guru dalam menjelaskan.

2. Siswa menjadi lebih bertanggung jawab terhadap tugas-tugasnya sebagai seorang pelajar.

3. Siswa bertambah kemampuan kognitifnya, paham akan materi yang disampaikan guru.

4. Siswa juga lebih aktif bekerja sama menghadapi kesulitan-kesulitan belajar matematika dengan saling membantu satu sama lainnya

Berdasarkan hasil di atas, secara keseluruhan penelitian tidakan kelas mengenai model pembelajaran kooperatif tipe STAD pada pelajaran matematika kelas VII materi SPLDV dapat dikatakan berhasil karena pada akhir penelitian kriteria keberhasilan yang ditetapkan telah terpenuhi yaitu dapat meningkatkan hasil belajar siswa sesuai dengan KKM yang ditentukan.

\section{SIMPULAN}

Dari penelitian tindakan kelas yang telah dilaksanakan, maka dapat ditarik simpulan bahwa pembelajaran kooperatif tipe STAD merupakan model yang efektif untuk menyampaikan materi SPLDV,
Pembelajaran dalam kelompok kecil dapat meningkatkan kemampuan penguasaan konsep materi matemarika dari siswa. Selain itu, dengan kelompok kecil ini kerja sama diantara siswa dapat tercipta dengan lebih baik lagi, dan hasil Penelitian ini bisa menjadi contoh untuk guru lain jika menghadapi masalah yang relatif sama.

\section{DAFTAR PUSTAKA}

[1] S. Arikunto, penelitian suatu pendekatan praktik. Yogyakarta: Rineka Cipta, 2009.

[2] Hasbullah, Pedoman praktis bagi guru professional. Jakarta: Unindra Press, 2015.

[3] Widyantini, Penerapan Pendekatan Kooperatif STAD dalam Pembelajaran Matematika SMP. Yogyakarta: P4TK Matematika, 2008.

[4] H. A. Lamba, "Model STAD dan gaya kognitif terhadap hasil belajar fisika siswa SMA" J. Ilmu Pendidik., vol. 13, no. 15, pp. 122-128, 2000.

[5] Alfiliansi, D. Ismaimuza, and S. Rochaminah, "Penerapa model pembelajaran kooperatif tipe STAD belajar siswa pada penjumlahan dan pengurangan," J. Elektron. Pendidik. Mat. Tadulako, vol. 2, no. 2, p. 134, 2014.

[6] N. Made Sunilawati, N. Dantes, and I. Made Candiasa, "Pengaruh model pembelajaran kooperatif tipe STAD terhadap hasil belajar matematika ditinjau dari kemampuan numerik siswa. e-Journal Program Pascasarjana Universitas Pendidikan Ganesha," $e$ Journal Progr. Pascasarj. Univ. Pendidik. Ganesha, vol. 3, p. 8, 2013. 